\title{
Declaration Patent for the Invention of Device for Pulling Halyard
}

G.E. Anuprienko, Y.A. Karpachov, M.S. Rowland, Y.M. Savenko, C.F. Smith

\section{January 31, 2002}

Lawrence

Livermore

National

Laboratory 


\section{DISCLAIMER}

This document was prepared as an account of work sponsored by an agency of the United States Government. Neither the United States Government nor the University of California nor any of their employees, makes any warranty, express or implied, or assumes any legal liability or responsibility for the accuracy, completeness, or usefulness of any information, apparatus, product, or process disclosed, or represents that its use would not infringe privately owned rights. Reference herein to any specific commercial product, process, or service by trade name, trademark, manufacturer, or otherwise, does not necessarily constitute or imply its endorsement, recommendation, or favoring by the United States Government or the University of California. The views and opinions of authors expressed herein do not necessarily state or reflect those of the United States Government or the University of California, and shall not be used for advertising or product endorsement purposes.

This work was performed under the auspices of the U.S. Department of Energy by the University of California, Lawrence Livermore National Laboratory under Contract No. W-7405-Eng-48.

This report has been reproduced directly from the best available copy.

Available electronically at http://www.doe.gov/bridge

Available for a processing fee to U.S. Department of Energy

and its contractors in paper from

U.S. Department of Energy

Office of Scientific and Technical Information

P.O. Box 62

Oak Ridge, TN 37831-0062

Telephone: (865) 576-8401

Facsimile: (865) 576-5728

E-mail: reports@adonis.osti.gov

Available for the sale to the public from

U.S. Department of Commerce

National Technical Information Service

5285 Port Royal Road

Springfield, VA 22161

Telephone: (800) 553-6847

Facsimile: (703) 605-6900

E-mail: orders@ntis.fedworld.gov

Online ordering: http://www.ntis.gov/ordering.htm

OR

Lawrence Livermore National Laboratory

Technical Information Department's Digital Library

http://www.llnl.gov/tid/Library.html 


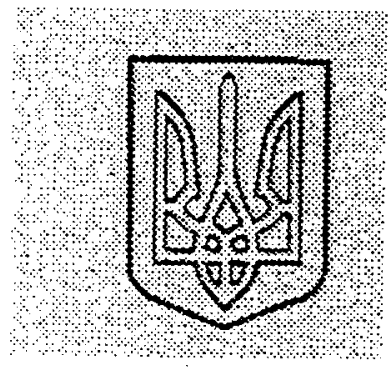

Ukraine

(19) (UA)

(11) $36478 \mathrm{~A}$

(51) $6 \mathrm{H} 02 \mathrm{G} 1 / 02$

\section{Ministry of education and sciences of Ukraine \\ State department of the intellectual property}

\section{Declaration patent for the invention}

Is registered according to the Law of Ukraine "About protection of rights on the inventions and useful models" from December 15, 1993 N3687-XII in edition from June 1, 2000 N1771-III

(21) 99127033

(22) 23.12 .1999

(24) 16.04 .2001

(46) 16.04.2001. Бюл. № 3

(72) Anuprienko Gennadiy Efremovych, Karpachov Yuriy Andiyovych, Rowland Mark Stephan(US), Savenko Yuriy Mykolayovych, Smith Craig F. (US)

(73) Ukrainian national technical University "Kyiv Politechnical Institute" 


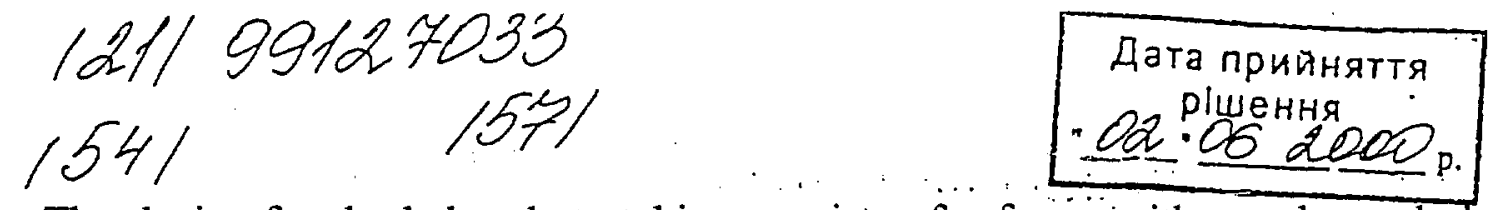

The device for the halyard stretching consists of a frame with coupler and clamping rollers mounted in pairs on it, the drive of the rotation of the coupler rollers and the clamping device with a clamping spring. The clamping device is remarkable that the clamping rollers are mounted in a separate movable bracket, which is connected with the frame with the help of a hinge. Between the frame and the movable bracket a releasing spring is inserted. The clamping device is equipped with a movable holder to clamp rollers kinematically connected with the coupler ones with the aid of cardan joints. It assures rotations of the movable bracket over the frame and synchronous rotation of the coupler and clamping rollers in different directions. All rollers are connected with the drive of rotation via an electro magnet sleeve. A linear drive of spring pressing is mounted between the movable bracket and the clamping spring. A nip of the releasing spring is connected with the electromagnet rotor.

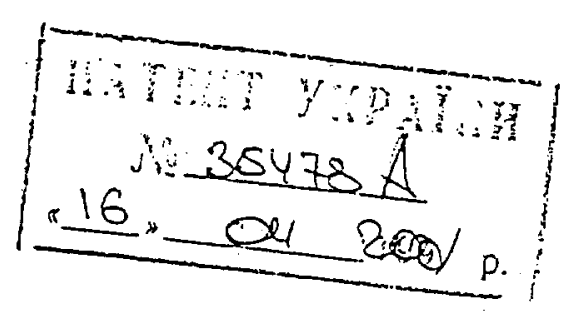


